\title{
Lys og varme
}

\begin{abstract}
Johan Jacob Reinhardt Natvig, mannen som fikk ideen til å utnytte Larviks-kilden («Kong Haakons kilde») til taffelvann (Farris), skriver i Tidsskriftet nr. 19/1934 om terapeutisk bestråling med rødt lys. Behandlingen skulle være effektiv ved en rekke tilstander, men Natvig selv hadde kun brukt den ved nevralgier. De gunstige resultatene underbygges av 21 kasuistikker. Bestråling er et bombardement av elektriske partikler med forskjellig bølgelenge og svingetall og dermed ulik biologisk virkning, forteller han (Tidsskr Nor Lægeforen 1934; 54: $975-80)$.
\end{abstract}

\section{Rødlys-bestråling.}

\section{Av J. Reinhardt Natvig, Oslo.}

Efter den referatlitteratur å dømme, som har stått til min rådighet, synes der ikke i de senere år å være skrevet meget om bestråling med rødt lys. Hovedinteressen har samlet sig om ultrafiolett. Dosentene F. Ludwig og J. v. Ries, Engeriedhospitalet i Bern, beretter om nogen interessante forsøk, de har gjort. Under bestråling med ultrafiolett dannes av hudkjertlenes cholesterin det antirakitiske Dvitamin (vigantrol). Dette blir inaktivert ved rødt lys og atter aktivert ved ultrafiolett, men den opnådde effekt igjen hevet ved rødt. Rotter, som blir opdrettet i rødt lys, utvikler sig til kraftige, friske kjempedyr, mens de, som vokser op i blålys, svarer til kontrolldyrene. Maur skyr blått lys og søker det røde. I et forsøk anbragtes dyrene i en kasse med rødt og i en kasse med blått glass. Blev rødt glass erstattet med blått, trakk dyrene sig straks tilbake i rødlyskassen. Det kvinnelige cyklushormon, progynon, influeres ikke av røntgenstråler, blir ødelagt av ultrafiolett, men aktiveres dobbelt til femdobbelt av rødt. Ultrafiolett er således ikke den eneste biologisk virksomme strålekvalitet i spektret.

Det angis, at rødlysbestråling er indisert ved alle beskadigelser gjennem ultrafiolett, ved ikke-rakitiske vekstforstyrrelser hos barn, ved sterke hudpigmenteringer, ved hypofunksjon av slektskjertlene, eventuelt også ved hypertyreoidismus, da skjoldbruskkjertelens substans tydelig blir hemmet i sin virkning under rødlysbestråling. A. Fra if eld (Moskva) minner om den heldige innflydelse av rødt lys på kopper (F i n s e n), meslinger og skarlagensfeber, på mange dermatoser, arteriosklerotisk gangræn, hudsår, adnekslidelser, lumbago m. m. Rødt lys fremkaller en dybdehyperemi og lindrer kvartslysdermatitt. Han anfører, at resorpsjon av et plevritisk ekssudat så vel som ved en kronisk pneumoni kan bli overraskende befordret ved rødlysbestråling. Erfaringer innen gynekologien foreligger fra prof. H. Kü s t n e r, Leipzig.

Jeg har de siste to år behandlet en gruppe lidelser med rødt lys ved hjelp av et hendig lite instrument, konstruert av $\mathrm{h}$ of $\mathrm{rat}, \mathrm{dr}$. The n e n i Wien. Instrumentet kaller han «Thermassor». Prof. di Gasparo, Graz, har først gjort opmerksom herpå i en meget rosende artikkel.

«Denne «Thermassor», sier han fortjener å bli et terapevtisk almengode i alle land. Den bør finne inngang ikke bare i de offentlige og private sykehus, men også i alle lægekontorer, ja like til patientens sykeseng.» Som det fremgår av billedet består instrumentet av en liten nedad åpen kasse med et håndtak, forsynt med en ledningssnor til lysledningen. Det leveres til 110-220 volt eller 210-250 volt (veksel- eller likestrøm). Nedad i kassen er innenfor et beskyttelsesgitter anbragt to horisontalt liggende metallstaver av nikkelkromat og magnesit, som tjener som glødelegemer. Det riflete

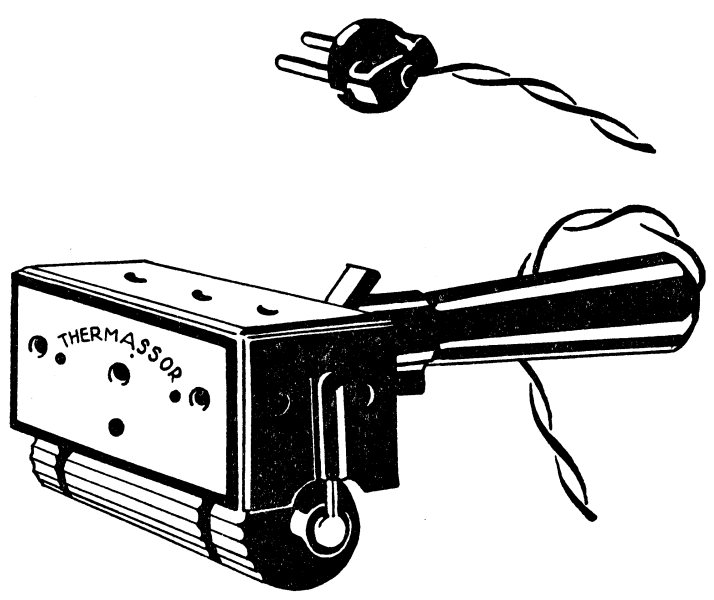

parti, man ser under kassen, er en kautsjukrulle, som kan brukes som massasjerulle på større hudflater under samtidig kontakt- og strålevarme. Den kan anbringes og fjernes ved et enkelt håndgrep. Selv har jeg kun anvendt til bestråling og like overfor en gruppe lidelser, som ofte forvolder vanskeligheter, nemlig nevralgier. Experimenti causa har jeg i nedenstående tilfelle kun anvendt bestråling, og de opnådde resultater har vært så opmuntrende, at jeg har funnet å burde gjøre andre kolleger delaktig deri. Også i en del kompliserte tilfelle er bestråling blitt anvendt ved siden av andre midler; men jeg lar disse uomtalt, da det er vanskelig å skjelne mellem virkningen av de enkelte behandlingsmomenter. Glødelegemene er tilstrekkelig opvarmet etter et par minutter. Instrumentet føres så frem og tilbake over hudoverflaten $i$ få $\mathrm{cm} . \mathrm{s}$ avstand. Det inntrer snart en synlig hyperemi, uten svedavsondring ; patientens hud kjennes het, men den syke angir bestrålingsvarmen som behagelig. Hos enkelte angis en utstråling til fjernere områder. Vi har før alltid vært vant til å betrakte varme som varme og lys som lys ; men vi vet jo nu, at disse såvel som andre usynlige strålekvaliteter kun er forskjellige uttrykksformer for elektriske svingninger. Teoretisk må vi derfor være berettiget til å betragte enhver bestrålingskvalitet som et bombardement av elektriske partikler, som kun skiller sig fra hverandre gjennem bølgelengde og svingetall, og derved betinget forskjellig biologisk virkning. Et annet spørsmål er, om disse bestrålingskvaliteter fra hudoverflaten ikke også virker i central retning. Irradiasjonen synes i enkelte tilfelle å tale for, at $\mathrm{Mackenzi} \mathrm{e} \mathrm{har} \mathrm{rett} \mathrm{i}$, at et perifert irritament, som projiseres centripetalt, i ryggmargen kan springe over på nærliggende centrer. 